\title{
The relationship between blood groups and acute myeloid leukemia
}

\author{
Kan grupları ve akut myeloid lösemi arasındaki ilişki
}

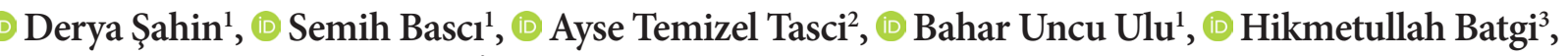

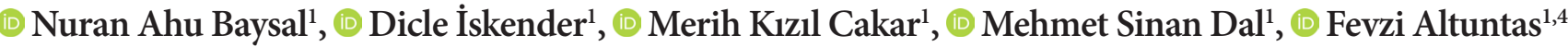 \\ ${ }^{1}$ Department of Hematology and Bone Marrow Transplantation Center, Ankara Dr. Abdurrahman Yurtaslan Oncology Training and Research \\ Hospital, University of Health Sciences, Ankara, Turkey \\ ${ }^{2}$ Department of Internal Medicine, Ankara Dr. Abdurrahman Yurtaslan Oncology Training and Research Hospital, University of Health \\ Sciences, Ankara, Turkey \\ ${ }^{3}$ Department of Hematology, Ankara Training and Research Hospital, Ankara, Turkey \\ ${ }^{4}$ Department of Internal Medicine and Hematology, Yıldırım Beyazıt University, Ankara, Turkey
}

Cite this article as / Bu makaleye atıf için: Şahin D, Başcı S, Temizel Taşçı A, et al. The relationship between blood groups and acute myeloid leukemia. J Health Sci Med 2020; 3(3): 221-224.

\begin{abstract}
Aim: Acute myeloid leukemia is an aggressive disease caused by a heterogeneous clonal disorder of hematopoietic progenitor cells that normally lose their ability to respond to differentiation and proliferation regulators. The main purpose is to identify and prevent the causes of acute leukemia. Although the etiology of acute leukemia has been investigated for many years, the exact cause is still unknown. Both $\mathrm{ABO}$ and $\mathrm{Rh}$ blood group systems have been associated with a number of diseases. The aim of this study was to investigate the relationship between AML and blood group types.

Material and Method: Between February 2014 and February 2018 The blood types of 163 AML patients treated in Abdurrahman Yurtaslan Ankara Oncology Training and Research Hospital were analyzed retrospectively. Age, sex, and blood group data of healthy platelet donors were used as a control group.

Results: The most common blood type in both men and women was A Rh-positive, no statistically significant difference was found between the control group and AML patients in terms of $\mathrm{ABO}$ blood group distribution. Rh positivity rate was similar between the patient group and healthy control group.

Discussion: We found that there is no relation between AML and $\mathrm{ABO}$ and $\mathrm{Rh}$ blood groups. Although there are larger studies confirming the relationship between solid tumors and $\mathrm{ABO}$ blood groups, studies on hematologic malignancies are fewer.

Cunclusion: A relationship between $\mathrm{AML}$ and $\mathrm{ABO}$ and $\mathrm{Rh}$ blood groups has not yet been clarified, more studies with more patients are needed.
\end{abstract}

Keywords: Blood group types, acute myeloid leukemia, leukemogenesis

\section{ÖZ}

Amaç: Akut miyeloid lösemi, normal olarak farklılaşma ve proliferasyon regülatörlerine cevap verme yeteneklerini kaybeden hematojen kök hücrelerin heterojen bir klonal bozukluğunun neden olduğu agresif bir hastalıktır. Ana amaç akut löseminin nedenlerini tanımlamak ve önlemektir. Akut lösemi etiyolojisi uzun yıllardır araştırılsa da, kesin nedeni hala bilinmemektedir. Hem ABO hem de Rh kan grubu sistemleri bir takım hastalıklarla ilişkilendirilmiştir. Bu çalışmanın amacı AML ve kan grubu tipleri arasındaki ilişkiyi araştırmaktır.

Gereç ve Yöntem: Şubat 2014 ve Şubat 2018 tarihleri arasında Abdurrahman Yurtaslan Ankara Onkoloji Eğitim ve Araştırma Hastanesi’nde tedavi edilen 163 AML hastasının kan tipleri retrospektif olarak incelendi. Sağlıklı trombosit vericilerinin yaş, cinsiyet ve kan grubu verileri kontrol grubu olarak kullanıldı.

Bulgular: Hem erkeklerde hem de kadınlarda en yaygın kan grubu A Rh pozitifti, kontrol grubu ile AML hastaları arasında ABO kan grubu dağılımı açısından istatistiksel olarak anlamlı bir fark bulunmadı. Rh pozitiflik oranı hasta grubu ile sağlıklı kontrol grubu arasında benzerdi.

Tartışma: AML ile ABO ve Rh kan grupları arasında bir ilişki bulunmadı. Solid organ tümörleri ile ABO kan grupları arasındaki ilişkiyi doğrulayan daha büyük çalışmalar olmasına rağmen, hematolojik kanserler üzerine çalışmalar daha azdır.

Sonuç: AML ile ABO ve Rh kan grupları arasında bir ilişki henüz açıklığa kavuşmamıştır, daha fazla hastayla daha fazla çalışmaya ihtiyaç vardir.

Anahtar Kelimeler: Kan grubu tipleri, akut miyeloid lösemi, lökomojenez 


\section{INTRODUCTION}

Acute myeloid leukemia (AML) is an aggressive disease caused byaheterogeneousclonaldisorder ofhematopoietic progenitor cells that normally lose their ability to respond to differentiation and proliferation regulators (1). It is the most common type of acute leukemia in adults and its incidence is $5-8 / 100,000(2,3)$. The main purpose is to identify and prevent the causes of acute leukemia. Gene mutations such as Wilms tumor 1 (WT1), FMSlike tyrosine kinase 3 (FLT3), or nucleophosmin (NPM) could be seen in AML patients (4). Although the etiology of acute leukemia has been investigated for many years, the exact cause is still unknown.Leukemogenesis is a multi-stage process that develops as a result of the sensitivity of a hematopoietic progenitor cell to the agent involved in the etiology. Different subtypes of acute leukemia may have different causal mechanisms, such as a separate molecular abnormality or mutation, and agent in the etiology.The pathogenesis of acute leukemia patients includes a complex chain of events that alter the proliferation and differentiation of hematopoietic precursor cells, chromosomal translocations, inversions, or point mutations $(2,3)$.

Today, the number of serologically defined blood group antigens is more than 600. Most of the blood group antigens are glycoproteins and are generally identified according to their oligosaccharide or amino acid sequence. Antigens of the $\mathrm{ABO}$ blood group system are found on the extracellular surface of erythrocyte membranes and these antigens are defined as complex carbohydrate molecules.In addition to the $\mathrm{ABO}$ blood group system, the $\mathrm{Rh}$ blood group is present and consists of at least 45 independent antigens.Both $\mathrm{ABO}$ and $\mathrm{Rh}$ blood group systems have been associated with a number of diseases.In some studies, $\mathrm{ABO}$ blood group system has been shown to play a role in the development of cardiovascular, oncologic and other diseases (5). Blood group antigens are known to participate in cell recognition and cell adhesion. Therefore, they are likely to play a role in tumor formation, metastasis, and prognosis (6).

After the discovery of a relationship between gastric cancer and blood group-A in 1953, studies were conducted on the possible relationship between blood groups and certain diseases (7). In a prospective study of a cohort of middle-aged and elderly Chinese males by Huang et al.(8) the overall risk of cancer was lower for the blood group $\mathrm{B}$ and lower in the $\mathrm{B}$ and $\mathrm{AB}$ blood groups compared to the blood group A in gastrointestinal cancers, including gastric and colorectal cancer.In contrast, this study showed a higher risk of liver cancer for the blood group $\mathrm{AB}$ and a lower risk of bladder cancer for the blood group $B$. These findings suggest that in addition to red blood cells, $\mathrm{ABO}$ blood group antigens are also expressed in epithelial cells of the gastrointestinal and urinary tract and the role of $\mathrm{ABO}$ blood groups in the development of epithelial cancers in the gastrointestinal and urinary tract.

For many years, the role of $\mathrm{ABO}$ blood group antigens in the development of cancer has been suspected. Since Aird et al. (7) first reported the relationship between peptic ulcer and gastric carcinoma and $\mathrm{ABO}$ blood groups, several studies have been conducted on this issue. Previous studies, mostly in Western populations, have found an increased risk of gastric cancer in individuals with blood group A of about 20\% (8). All of these studies have demonstrated that the relationship between solid tumors and $\mathrm{ABO}$ blood group has been suspected to be the same in hematologic cancers, but there are fewer studies investigating the relationship between hematologic cancers and $\mathrm{ABO}$ blood groups. Iodis et al. (9) reported that there was a significant difference in the distribution of blood group $\mathrm{O}$ in Hodgkin lymphoma and Non-Hodgkin Lymphoma. The aim of this study was to investigate the relationship between AML and blood groups.

\section{MATERIAL AND METHOD}

Between February 2014 and February 2018, the blood types of 163 AML patients treated in Abdurrahman Yurtaslan Ankara Oncology Training and Research Hospital were analyzed retrospectively. This study was approved by the university /local human research ethics committee and all procedures performed in studies involving human participants were in accordance with the ethical standards of the institutional and/ or national research committee and with the 1964 Helsinki Declaration and its later amendments or comparable ethical standards. The study was carried out with the permission of Health Sciences University Dr. Abdurrahman Yurtaslan Oncology Health Practice and Research Center Clinical Research Ethics Committee (Permission granted: 06.11.2019, Decision no: 201911/446). The patients were diagnosed as AML by examination of morphological findings of bone marrow aspirates and leukemic cells by flow cytometry or immunohistochemical analysis. Age, sex, and blood group data of healthy platelet donors were used as a control group.

IBM SPSS Statistics (version 21) software was used for statistical analysis. Descriptive statistics were used to summarize the data. Categorical data were expressed as a ratio, and numerical data were expressed as median and mean \pm standard deviation. Categorical variables analyzed with Chi-Square test. $\mathrm{P}$ values of $\leq 0.05$ were considered statistically significant. 


\section{RESULTS}

Of the 163 patientsincluded in the study, $67(41.1 \%)$ patients were women and $96(58.9 \%)$ were men. The median age was 46 (range 15-86) in all AML patients, 49 (range 15-80) in women, and 43 (range 18-86) in men. The blood group distribution of AML patients is shown in Table 1.The blood group distribution of healthy donors is shown in Table 2.

\begin{tabular}{|lccc|}
\hline \multicolumn{4}{|l|}{ Table 1. Blood group distribution in AML patients } \\
\hline Blood group & Female (n) & Male (n) & Total (n) \\
\hline 0 RH (-) & 3 & 1 & 4 \\
0 RH (+) & 24 & 39 & 63 \\
A RH (-) & 3 & 4 & 7 \\
A RH (+) & 20 & 33 & 53 \\
AB RH (-) & 1 & 1 & 2 \\
AB RH (+) & 4 & 4 & 8 \\
B RH (-) & 1 & 1 & 2 \\
B RH (+) & 11 & 13 & 24 \\
\hline Total & 67 & 96 & 163 \\
\hline
\end{tabular}

\begin{tabular}{|lccc|}
\hline \multicolumn{4}{|l|}{ Table 2. Blood group distribution in healty donors } \\
\hline Blood group & Female (n) & Male (n) & Total (n) \\
\hline 0 RH (-) & 5 & 5 & 10 \\
0 RH (+) & 17 & 41 & 58 \\
A RH (-) & 5 & 2 & 7 \\
A RH (+) & 11 & 74 & 85 \\
AB RH (-) & 0 & 7 & 7 \\
AB RH (+) & 3 & 13 & 16 \\
B RH (-) & 0 & 3 & 3 \\
B RH (+) & 5 & 15 & 20 \\
\hline Total & 46 & 160 & 206 \\
\hline
\end{tabular}

AML patients and healthy controls were similar in terms of gender and age distribution. Although the most common blood type in both men and women was A Rhpositive, no statistically significant difference was found between the control group and AML patients in terms of $\mathrm{ABO}$ blood group distribution (p:0.731). When $\mathrm{Rh}$ characteristics were evaluated, The Rh positivity rate was similar between the patient group and the healthy control group $(\mathrm{p}=0.376)$.

\section{DISCUSSION}

For many years, the role of $\mathrm{ABO}$ blood group antigens in the development of cancer has been suspected. Since Aird et al. (7) first reported the relationship between peptic ulcer and gastric carcinoma and $\mathrm{ABO}$ blood types, numerous studies have been conducted on this issue. Blood group antigens are known to participate in cell recognition and cell adhesion due to their specific properties. Therefore, they are likely to play a role in tumor formation, metastasis, and prognosis (6). All of these studies have demonstrated that the relationship between solid tumors and $\mathrm{ABO}$ blood group has been suspected to be the same in hematologic cancers, but there are fewer studies investigating the relationship between hematologic cancers and $\mathrm{ABO}$ blood groups.Several studies have reported conflicting results regarding the relationship between blood groups and acute leukemia $(10,11)$

Nagy et al. (12) showed an increase in the rate of blood group $\mathrm{O}$ in female patients with acute leukemia. Jackson et al. (13) reported a decrease in the rate of blood group $\mathrm{O}$ in female patients with acute leukemia. In the study conducted by Sadeghian et al. (14) although there was no significant relationship between $\mathrm{ABO}$ and $\mathrm{Rh}$ blood groups and acute leukemia, blood group $\mathrm{B}$ was found to be more common in female patients .

Alavi et al. (15) found a higher rate of group A in patients with AML. In their study Vadivelu et al. (16) ABO blood group distribution in Indian patients with AML was found to be similar to the normal population. In the study conducted by Kar et al. (17) in Turkish patients with AML blood group A and Rh positivity rate was more common but they could not find a statistically significant difference.

\section{CONCLUSION}

In conclusion, we found that there is no relation between $\mathrm{AML}$ and $\mathrm{ABO}$ and Rh blood groups. Although there are larger studies confirming the relationship between solid tumors and $\mathrm{ABO}$ blood groups, studies on hematologic malignancies are fewer.Therefore, this issue has not been clarified yet, more studies with more patients are needed.

\section{ETHICAL DECLARATIONS}

Ethics Committee Approval: The study was carried out with the permission of Health Sciences University Dr. Abdurrahman Yurtaslan Oncology Health Practice and Research Center Clinical Research Ethics Committee (Permission granted: 06.11.2019, Decision no: 201911/446).

Informed Consent: Because the study was designed retrospectively, no written informed consent form was obtained from patients.

Referee Evaluation Process: Externally peer-reviewed.

Conflict of Interest Statement: The authors have no conflicts of interest to declare.

Financial Disclosure: The authors declared that this study has received no financial support. 
Author Contributions: All of the authors declare that they have all participated in the design, execution, and analysis of the paper, and that they have approved the final version.

\section{REFERENCES}

1. Mohty M. Indications for HSCT in adults: acute myeloid leukaemia. In: Appertley J, Carreras E, Gluckan E, Masszi T, editors. The EBMT handbook - haematopoietic stem cell transplantation. 6. ed. Paris: ESH - European School of Haematology; 2012: 317-29.

2. Fey MF, Buske C. ESMO Guidelines Working Group. Acute myeloblastic leukaemias in adult patients: ESMO clinical practice guidelines for diagnosis, treatment and follow-up. Ann Oncol 2013; 24: 38-43.

3. De Kouchkovsky I, Abdul-Hay M. Acute myeloid leukemia: a comprehensive review and 2016 update. Blood Cancer J 2016; 6: e441.

4. Merdin A, Dal MS, Çakar MK, et al. Analysis of pre-chemotherapy WBC, PLT, monocyte, hemoglobin and MPV levels in acute myeloid leukemia patients with WT1, FLT3 or NPM gene mutations . Medicine 2020; 99: 14(e19627).

5. Franchini M, Favaloro EJ, Targher G, Lippi G. ABO blood group, hypercoagulability, and cardiovascular and cancer risk. Crit Rev Clin Lab Sci 2012; 49: 137-49.

6. Weisbrod AB, Nilubol N, Weinstein LS, et al. Association of type-O blood with neuroendocrine tumors in multiple endocrine neoplasia type 1. J Clin Endocrinol Metab 2013; 98: 109-14.

7. Aird I, Bentall HH, Roberts JF. Relationship between cancer of stomach and the ABO bloodgroups. Br Med J. 1953; 1: 799.

8. Huang JY, Wang R, Gao YT, Yuan JM. ABO blood type and the risk of cancer - findings from the Shanghai Cohort study. PLoS One 2017; 12: e0184295.

9. Iodice S, Maisonneuve P, Botteri E, Sandri MT, Lowenfels AB. ABO blood group and cancer. Eur J Cancer 2010; 46: 3345-50.

10. Novaretti M, Domingues A, Manhani R, Pinto E, Dorlhiac-Llacer $\mathrm{P}$, Chamone $\mathrm{D}$. ABO genotyping in leukemia patients reveals new $\mathrm{ABO}$ variant alleles. Genet Mol Res 2008; 7: 87-94.

11. Amundadottir L, Kraft P, Stolzenberg-Solomon RZ, et al. Genome-wide association study identifies variants in the $\mathrm{ABO}$ locus associated with susceptibility to pancreatic cancer. Nature genetics. 2009; 41: 986- 90.

12.Nagy P, Jako J, Kiss A, Tamas E, Telek B, Rak K. Sex-lınked difference in blood-group distribution among patients suffering from acute leukaemias. British journal of haematology. 1981; 48: 507-12.

13. Mustacchi P, Shonfeld EM, Lucia S. Survival in acute leukemia: the influence of blood groups, sex, and age at onset Ann Intern Med 1960; 52: 1099-107.

14. Sadeghian $\mathrm{MH}$, Ebrahimzadeh S. Frequency of $\mathrm{ABO}$ and $\mathrm{Rh}$ blood groups in patients with acute leukemia. J Gorgan Uni Med Sci 2011; 13: 121-6.

15. Alavi S, Ashraf H, Rashidi A, Hosseini N, Abouzari M, Naderifar M. Distribution of $\mathrm{ABO}$ blood groups in childhood acute leukemia. Pediatr Hematol Oncol 2006; 23: 611-7.

16. Vadivelu MK, Damodaran S, Solomon J, Rajaseharan A. Distribution of $\mathrm{ABO}$ blood groups in acute leukaemias and lymphomas. Ann Hematol 2004; 83: 584-7.

17. Kar F, Andıç N,Kiraz Z, et al. Distribution of blood groups in different types of leukemia patients in Eskişehir, Turkey. Turkish J Life Sciences. 2018; 3: 214-7. 